\title{
Optimization of multiple quality characteristics of EDM process for MRR and TWR using utility concept
}

\author{
Malhotra, $\mathbf{N}$. \\ Department of Mechanical Engineering, YMCA University of Science \& Technology, Faridabad, India - 121006
}

\section{A B S T R A C T}

Electrical discharge machining (EDM) researchers have explored a number of ways to improve the material removal rate $(M R R)$ in order to meet the industrial need for fulfilling market demand. Tool wear rate $(T W R)$ is also one of the important performance measures in EDM amongst other measures such as metal removal rate and surface roughness. In most EDM operations, the contribution of the tool cost to the operational costs is more than $70 \%$. As a consequence, the wear of the tool should be carefully taken into consideration when planning and designing EDM operations. Despite a range of different approaches, this new research shares the same objective of achieving more efficient material removal coupled with a simultaneous reduction in tool wear. This study reports on an investigation into the optimization of the die sink EDM process on EN31 die steel. Taguchi's method with multiple performance characteristics has been adopted to obtain an overall utility value that represents the overall performance of die sink EDM. The six input parameters are optimized by considering multi-performance characteristics including $M R R$ and TWR. The predicted optimal values for MRR and TWR obtained for die sink EDM are $0.2421 \mathrm{~g} / \mathrm{min}$ and $0.0087 \mathrm{~g} / \mathrm{min}$, respectively. The results were verified by conducting confirmation experiments.
\end{abstract}

\section{ARTICLE INFO}

Keywords:

Electrical discharge machining

Taguchi method

Utility concept

Optimization

Corresponding author:

navdeep_malhotra2001@yahoo.com (Malhotra, N.)

Article history:

Received 2 May 2013

Revised 13 November 2013

Accepted 25 November 2013

\section{References}

[1] Buchacz, A. (2008). Investigation of piezoelectric in influence on characteristics of mechatronic system. Journal of Achievements in Materials and Manufacturing Engineering, Vol. 26, 41-48.

[2] Khanra, A.K., Pathak L.C., Godkhindi, M.M. (2009). Application of new tool material for electrical discharge machining (EDM), Bulletin of Material Science, Vol. 40, No. 4, 401-405, doi: 10.1007/s12034-009-0058-0.

[3] Yan, B.H., Chen, S.L. (1993). Effects of dielectric with suspended aluminum powder on EDM, Journal of the Chinese Society of Mechanical Engineers, Vol. 14, 307-312.

[4] Taguchi, G. (1988). Introduction to quality engineering: designing quality into products and processes, Asian Productivity Organisation, Tokyo.

[5] Ross, P.J. (1988). Taguchi techniques for quality engineering, McGraw Hill, New York.

[6] Roy, R.K. (1990). A primer on the Taguchi methods, Van Nostrand Reinhold, New York.

[7] Jeswani, M.L. (1978). Roughness and wear characteristic of spark-eroded surface, Wear, Vol. 51, 227-236, doi: 10.1016/0043-1648(78)90262-4.

[8] Longfellow, J., Wood, J.D., Palme, R.B. (1968). The effects of electrode material properties on the wear ratio in spark machining, Journal of the Institute of Metals, Vol. 96, 43-48.

[9] Pandit, S.M., Rajurkar, K.P. (1980). Crater geometry and volume from electro-discharge machined surface profiles by data dependent system, Journal of Engineering for Industry, Vol. 102, No. 4, 289-295, doi: 10.1115/1.3183867.

[10] Marafona, J., Wykes, C. (2000), A new method of optimizing material removal rate using EDM with coppertungsten electrodes, International Journal of Machine Tools and Manufacturing, Vol. 40, No. 2, 153-164, doi: 10.1016/S0890-6955(99)00062-0. 
[11] Tsai, K.-M., Wang, P.-J. (2001). Semi-empirical model of surface finish on electrical discharge machining, International Journal of Machine Tools and Manufacturing, Vol. 41, No. 10, 1455-1477, doi: 10.1016/S0890-6955(01) 00015-3.

[12] Erden, A. (1983). Effect of materials on the mechanism of electric discharge machining (E.D.M.), Journal of Engineering Materials and Technology, Vol. 105, No. 2, 132-138, doi: 10.1115/1.3225627.

[13] Yu, Z.Y., Masuzawa, T., Fujino, M. (1998). Micro-EDM for three-dimensional cavities - development of uniform wear method, CIRP Annals - Manufacturing Technology, Vol. 47, No. 1, 169-172, doi: 10.1016/S0007-8506(07) 62810-8.

[14] Bleys, P., Kruth, J.-P., Lauwers, B., Zryd, A., Delpretti, R., Tricarico, C. (2002). Real-time tool wear compensation in milling EDM, CIRP Annals - Manufacturing Technology, Vol. 51, No. 1, 157-160, doi: 10.1016/S0007-8506(07) 61489-9.

[15] Tricarico, C., Delpretti, R., Dauw, D.F. (1988). Geometrical simulation of the EDM die-sinking process, CIRP Annals - Manufacturing Technology, Vol. 37, No. 1, 191-196, doi: 10.1016/S0007-8506(07)61616-3.

[16] Osyczka, A., Zimny, J., Zając, J., Bielut, M. (1982). An approach to identification and multicreation optimization of EDM process, In: Proceedings of the 23rd International Machine Tool Design and Research Conference, Manchester, 291-296.

[17] Lin, J.L., Wang, K.S., Yan, B.H., Tarng, Y.S. (2000). An investigation in to improving worn electrode reliability in the electrical discharge machining process, The International Journal of Advanced Manufacturing Technology, Vol. 16, No. 2, 113-119, doi: 10.1007/s001700050016.

[18] Lin, Y.C., Yan, B.H., Huang, F.Y. (2001). Surface improvement using a combination of electrical discharge machining with ball burnish machining based on the Taguchi method, The International Journal of Advanced Manufacturing Technology, Vol. 18, No. 9, 673-682, doi: 10.1007/s001700170028.

[19] Lin, J.L., Lin, C.L. (2002). The use of the orthogonal array with grey relational analysis to optimize the electrical discharge machining process with multiple performance characteristics, International Journal of Machine Tools and Manufacture, Vol. 42, No. 2, 237-244, doi: 10.1016/S0890-6955(01)00107-9.

[20] Lin, J.L., Wang, K.S., Yan, B.H., Tarng, Y.S. (1999). Grey-based Taguchi method for optimizing the multi-response process, The Journal of Grey System, Vol. 11, No. 3, 257-277.

[21] Jangra, K., Jain, A., Grover, S. (2010). Optimization of multiple-machining characteristics in wire electrical discharge machining of punching die using Grey relational analysis, Journal of Scientific \& Industrial Research, Vol. 69, No. 8, 606-612.

[22] Shandilya, P., Jain, P.K., Jain, N.K. (2011). Modeling and analysis of surface roughness in WEDC of SiCP $6061 \mathrm{Al}$ MMC through response surface methodology, International Journal of Engineering Science and Technology, Vol. 3, No. 1, 531-535.

[23] Gadakh, V.S., Shinde, V.B. (2011). Selection of cutting parameters in side milling operation using graph theory and matrix approach, The International Journal of Advanced Manufacturing Technology, Vol. 56, No. 9-12, 857863, doi: 10.1007/s00170-011-3256-z.

[24] Gadakh, V.S. (2012). Parametric optimization of wire electrical discharge machining using TOPSIS method, Advances in Production Engineering \& Management, Vol. 7, No. 3. 157-164.

[25] Krishnamoorthy, A., Boopathy, S.R., Palanikumar, K., Davim, J.P. (2012). Application of grey fuzzy logic for the optimization of drilling parameters for CFRP composites with multiple performance characteristics, Measurement, Vol. 45, No. 5, 1286-1296, doi: 10.1016/j.measurement.2012.01.008.

[26] Sathisha, N., Somashekhar, S.H., Shivakumar, J., Jagannatha, N. (2013). Optimization of ECDM process parameters using Taguchi robust design and utility concept, International Journal of Emerging Trends in Engineering and Development, Vol. 2, 165-173.

[27] Bose, G.K., Mitra, S. (2013). Study of ECG process while machining $\mathrm{Al}_{2} \mathrm{O}_{3} / \mathrm{Al}-\mathrm{IPC}$ using grey-Taguchi methodology, Advances in Production Engineering \& Management, Vol. 8, No. 1, 41-51.

[28] Altan, T., Lilly, B.W., Kruth, J.P., König, W., Tönshoff, H.K., van Luttervelt, C.A., Khairy, A.B. (1993). Advanced techniques for die and mold manufacturing, CIRP Annals - Manufacturing Technology, Vol. 42, No. 2, 707-716 doi: 10. 1016/S0007-8506(07)62533-5.

[29] Liu, J., Zhao, J., Zhao, W. (2000). The non-conventional machining, China Machine Press, Peking.

[30] Tsai, H.C., Yan, B.H., Huang, F.Y. (2003). EDM performance of $\mathrm{Cr} / \mathrm{Cu}$-based composite electrodes, International Journal of Machine Tools and Manufacture, Vol. 43, No. 3, 245-252, doi: 10.1016/S0890-6955(02)00238-9.

[31] Boothroyd, G., Knight, W.A. (1989). Fundamentals of machining and machine tools, Marcel Dekker, New York.

[32] Kalpakjian, S., Schmid, S.R. (2003). Manufacturing processes for engineering materials, $4^{\text {th }}$ ed., Prentice Hall, New Jersey.

[33] König, W., Dauw, D.F., Levy G., Panten, U. (1988). EDM-future steps towards the machining of ceramics, CIRP Annals - Manufacturing Technology, Vol. 37, No. 2, 623-631, doi: 10.1016/S0007-8506(07)60759-8.

[34] Derek, W.B. (1982). Analysis for optimal decisions, John Wiley and Sons, New York.

[35] Gupta, V., Murthy, P.N. (1980). An introduction to engineering design methods, Tata McGraw-Hill, New Delhi. 